\title{
Effect of supplemental phytase to laying hen diets of different phosphorus content ${ }^{*}$
}

\author{
Barbara Z. Kamińska
}

\author{
Institute of Animal Production, \\ Department of Feed Science and Animal Products \\ 32-083 Balice, Poland
}

(Received 6 September 1996; accepted 19 August 1997)

\begin{abstract}
The experiment was carried out on 216 Hisex brown hens, aged 48-70 wecks, divided into 12 groups of 18 birds kept in single cages. Layers were fed diets containing $0.45,0.52$ and $0.58 \%$ total $\mathrm{P}(0.25,0.30,0.35 \%$ available $\mathrm{P})$ supplemented with $0,150,300$ or 450 units of microbial phytase (FTU) per kg. At 54, 62 and 70 weeks of age, eggs and egg-shell quality were analysed. Level of $P$ and phytase had no effect on feed intake, laying rate, yolk percentage and albumen:yolk ratio. Eggs were heaviest $(65.1 \mathrm{~g})$ when no phylase was added or when the diet containing the lowest $P$ level was fed $(\mathrm{P} \leqslant 0.01)$. Specilic gravity, shell breaking strength, shell thickness, shell percentage and shell index (density) were highest when the diets were supplemented with $150 \mathrm{FTU} / \mathrm{kg}$, regardless of the P level. However, differences wcre significant $(P \leqslant 0.05)$ only for shell breaking sirength and thickness. On the dicts supplemented with $450 \mathrm{FTL}$, some parameters of egg-shell quality were worse than without the addition of microbial phytase. I Iowever, a much smaller number of cracked and broken eggs was found when phytase was added.
\end{abstract}

KEY WORDS: layers, phosphorus, phytase, cgg weight, egg-shell quality

\section{INTRODUCTION}

In experiments on hens with laying rate under $80 \%$, reduction of available dietary phosphorous (AP) to $0.25 \%$ (Daghir et al., 1985), or even to $0.15 \%$ of diet (Rodriguez et al., 1984) did not reduce the number of eggs, despite the fact that microbial phytase had not been administered. On the other hand, when

* This study was supported by State Committee for Scientific Research grant No. 5 S30506104 
Usayran and Balnave (1995) supplemented the diets of hens with similar laying rates, with 500 phytase units (FTU), they found that performance declined by $4 \%$ when the diet contained $0.12 \% \mathrm{AP}$, and by $6 \%$ at AP level of $0.24 \%$.

When laying performance was above $90 \%$, it was found necessary either to supplement diets containing $0.25 \%$ AP with $300 \mathrm{FTU} / \mathrm{kg}$, or to give feeds with a $0.30 \%$ AP content without adding phytase, or with 150 FTU $/ \mathrm{kg}$ (Kamińska et al., 1996). A dietary phosphorous level of $0.25 \% \mathrm{AP} / \mathrm{kg}$ without phytase made it possible to achieve a laying rate of up to $85 \%$. These results show that the amount of supplementary phytase, an enzyme increasing the availability of $P$ from phytates, should be adjusted to the amount of available phosphorous in the diet and to the requirement of hens, which depends mainly on laying performance.

The objective of the current study was to examine the reaction of hens with laying rates of about $80 \%$ to different dietary phosphorous levels and to various levels of microbial phytase supplementation.

\section{MATERIAL AND METHODS}

The experiment was conducted from July 1994 to March 1995 on 216 Hisex Brown hens aged 48-70 weeks assigned to 12 groups of 18 birds kept individually in cages. They were fed ad libitum with one of three diets. All of the feed mixtures contained per kilogram (\%): ground wheat, 48.95; ground maize, 25 ; soyabean meal, $14(46 \% \mathrm{CP})$; meat meal $(62 \% \mathrm{CP}), 3.5 ; \mathrm{NaCl}, 0.3$; vitamin-mineral premix, $0.5 ; 11.45 \mathrm{MJ} \mathrm{AME}_{\mathrm{N}} ; 168 \mathrm{~g}$ of crude protein; $7.4 \mathrm{~g}$ Lys; $6.2 \mathrm{~g}$ Meth +Cyst; $1.8 \mathrm{~g}$ Try. The diets differed in the content of dicalcium phosphate and limestone, which amounted to 0.25 and $7.5,0.55$ and 7.2 , and 0.85 and $6.9 \%$, respectively, in diets 1,2 and 3 . It corresponded to $3.0 \mathrm{~g} \mathrm{Ca} ; 4.5$ and $2.5 ; 5.2$ and 3.0 , and 5.8 and $3.5 \mathrm{~g}$ total and available $\mathbf{P}$, per $\mathrm{kg}$ of diets 1,2 and 3 , respectively. Each of the diets was fed unsupplemented or supplemented with 150,300 or 450 units of phytase (FTU) $/ \mathrm{kg}$. Natuphos 5000 , phytase produced by Aspergillus niger, was used. One unit of phytase (FTU) is defined as the quantity of enzyme which liberates $1 \mu$ mole of inorganic P per min from $0.0015 \mathrm{~mol} / 1$ solution of sodium phytate at $\mathrm{pH} 5.5$ and $37^{\circ} \mathrm{C}$.

Feed consumption was measured for each hen for three consecutive days in the middle of the experiment. Eggs were collected daily and those laid on 5 consecutive days each month were weighed. At the age of 54,62 and 70 weeks, 12 eggs were taken from each groups for analysis. Egg weight, specific gravity, breaking strength (mcasured by applying pressure along the long axis of the egg), shell thickness in three points, yolk, egg white, and dry shell weight were determined percentage share of yolk, egg white and dry shell in total egg mass was calculated, as well as shell surface area (SSA) according to the formula: 


$$
\text { SSA = egg weight }{ }^{0.667} \times 4.67 .
$$

Shell density (shell index) was calculated as a weight of dry shell/SSA ( $\mathrm{mg} / \mathrm{cm}^{2}$ ).

The results were subjected to two-way ANOVA General Linear Models (GLM) analysis, SAS Institute (1985) with phosphorus and phytase levels as the main effects.

\section{RESULTS}

Laying rate

The amount of total and available phosphorous in diets did not affect the laying rate of the hens. It averaged in all groups $83 \%$ between 48 to 70 weeks of life (Table 1).

\section{Egg weight}

Hens fed the diet containing $0.45 \%$ TP $(0.25 \%$ available $\mathrm{P})$ without added phytase laid the heaviest eggs $(66.1 \mathrm{~g})$. Hens that did not receive phytase laid heavier eggs (65.1 g) than those on the phytase- supplemented diets (62.9-63.8 g) $(\mathrm{P} \leqslant 0.01$; Table 1). The differences in mean egg weight between groups recciving the lowest amount of dietary phosphorous and those receiving the highest ones were also significant $(\mathrm{P} \leqslant 0.01$; Table 1$)$.

\section{Feed consumption}

Feed consumption averaged $108 \mathrm{~g}$ daily per hen and was independent of the amount of phosphorous in the diet and the supplement of microbial phytase.

\section{Yolk percentage in egg}

The yolk constituted an average $28 \%$ of total egg mass. Its share in the egg did not change in relation to the amount of available phosphorous in the diet. The cgg white: yolk weight ratio averaged 2.24:1 (Table 1).

Specific gravity

No significant differences were found between groups in the specific gravity of eggs. 
TABLE 1

Effect of dietary phosphorus level and phytase supplement on performance of laying hens

\begin{tabular}{|c|c|c|c|c|c|c|c|c|}
\hline \multicolumn{2}{|c|}{ Dietary P, \% } & \multicolumn{4}{|c|}{ Phytase supplement FTL/kg diet } & \multirow{2}{*}{ Mean } & \multirow{2}{*}{ SEM } & \multirow{2}{*}{ PT $\times$ FTL } \\
\hline & $\mathbf{P}$ available & 0 & 150 & 300 & 450 & & & \\
\hline \multicolumn{9}{|c|}{ Laying rate, $\%$} \\
\hline 0.45 & 0.25 & 82.3 & 81.3 & 82.3 & 85.1 & 82.9 & 0.85 & \\
\hline 0.52 & 0.30 & 81.1 & 83.5 & 81.0 & 83.0 & 82.2 & 0.80 & NS \\
\hline 0.58 & 0.35 & 81.3 & 84.8 & 85.3 & 84.2 & 83.9 & 0.92 & \\
\hline Mean & & 81.5 & 83.2 & 82.9 & 84.2 & 83.0 & & \\
\hline SEM & & 0.69 & 0.82 & 0.90 & 0.84 & 0.76 & & \\
\hline \multicolumn{9}{|c|}{ Egg weight, g } \\
\hline 0.45 & 0.25 & 66.1 & 64.6 & 63.4 & 64.6 & $64.5^{\mathrm{A}}$ & 0.38 & \\
\hline 0.52 & 0.30 & 65.2 & 63.7 & 62.6 & 63.6 & $63.8^{\mathrm{B}}$ & 0.39 & NS \\
\hline 0.58 & 0.35 & 64.4 & 62,8 & 62.5 & 63.0 & $63.2^{\mathrm{B}}$ & 0.42 & \\
\hline Mean & & $65.1^{A}$ & $63.7^{\mathrm{B}}$ & $62.9^{\mathrm{C}}$ & $63.8^{\mathrm{B}}$ & 63.8 & & \\
\hline SEM & & 0.38 & 0.47 & 0.52 & 0.42 & 0.47 & & \\
\hline \multicolumn{9}{|c|}{ Feed intake, g/day } \\
\hline 0.45 & 0.25 & 107 & 107 & 106 & 110 & 107 & 0.99 & \\
\hline 0.52 & 0.30 & 110 & 106 & 103 & 110 & 107 & 1.18 & NS \\
\hline 0.58 & 0.35 & 111 & 106 & 109 & 107 & 108 & 1.11 & \\
\hline Mean & & 109 & 106 & 108 & 109 & 108 & & \\
\hline SEM & & 1.12 & 0.96 & 1.20 & 1.08 & 1.14 & & \\
\hline \multicolumn{9}{|c|}{ Yolk, \% } \\
\hline 0.45 & 0.25 & 28.9 & 27.8 & 27.1 & 28.0 & 27.9 & 0.19 & \\
\hline 0.52 & 0.30 & 28.2 & 27.8 & 28.4 & 28.4 & 28.2 & 0.18 & NS \\
\hline 0.58 & 0.35 & 27.9 & 27.8 & 28.6 & 28.9 & 28.3 & 0.20 & \\
\hline Mean & & 28.3 & 27.8 & 28.0 & 28.5 & 28.1 & & \\
\hline SEM & & 0.24 & 0.20 & 0.22 & 0.20 & 0.22 & & \\
\hline \multicolumn{9}{|c|}{ Albumen/yolk ratio } \\
\hline 0.45 & 0.25 & 2.17 & 2.28 & 2.34 & 2.26 & 2.26 & 0.022 & \\
\hline 0.52 & 0.30 & 2.23 & 2.27 & 2.22 & 2.20 & 2.23 & 0.020 & NS \\
\hline 0.58 & 0.35 & 2.27 & 2.26 & 2.18 & 2.15 & 2.22 & 0.023 & \\
\hline Mean & & 2.22 & 2.27 & 2.25 & 2.20 & 2.24 & & \\
\hline SEM & & 0.027 & 0.025 & 0.026 & 0.023 & 0.026 & & \\
\hline
\end{tabular}

$\mathrm{A}, \mathrm{B}, \mathrm{C}-\mathrm{P} \leqslant 0.01$

\section{Shell breaking strength}

The differences in shell breaking strength among groups were significant $(\mathrm{P} \leqslant 0.05$; Table 2$)$. The strongest shells $(4.01 \mathrm{~kg})$ were from hens receiving $150 \mathrm{FTU} / \mathrm{kg}$ of diet, the weakest $(3.74 \mathrm{~kg})$ from those receiving the highest (450 FTU/kg) supplementation. 
TABI.E 2

Egg specific gravity $\left(\mathrm{g} / \mathrm{cm}^{3}\right)$, breaking strenght $(\mathrm{kg})$, shell thickness $(\mu \mathrm{m})$ shell index $\left(\mathrm{mg} / \mathrm{cm}^{2}\right)$ and shell percent*

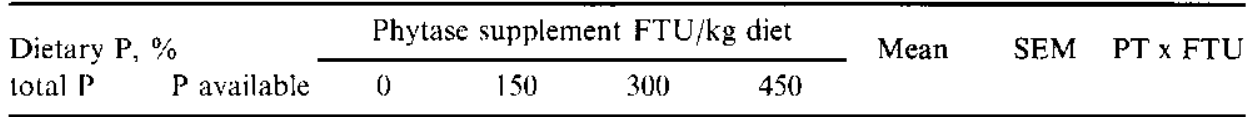

Specific gravity

$\begin{array}{lllllll}0.45 & 0.25 & 1.08 & 1.08 & 1.09 & 1.08 & 1.08 \\ 0.52 & 0.30 & 1.08 & 1.08 & 1.08 & 1.08 & 1.08 \\ 0.58 & 0.35 & 1.08 & 1.09 & 1.08 & 1.08 & 1.08 \\ \text { Mean } & & 1.08 & 1.09 & 1.08 & 1.08 & 1.08 \\ \text { SEM } & & 0.0008 & 0.0008 & 0.0008 & 0.0007 & 0.0008\end{array}$

Breaking strength

$\begin{array}{lllllllll}0.45 & 0.25 & 3.96 & 4.00 & 4.09 & 3.50 & 3.88 & 0.076 & \\ 0.52 & 0.30 & 3.76 & 4.08 & 4.05 & 3.91 & 3.95 & 0.083 & \text { NS } \\ 0.58 & 0.35 & 4.10 & 3.94 & 3.64 & 3.81 & 3.87 & 0.073 & \\ \text { Mean } & & 3.94^{\text {ab }} & 4.01^{\text {a }} & 3.93^{\text {ab }} & 3.74^{\mathrm{b}} & 3.90 & & \\ \text { SEM } & & 0.098 & 0.085 & 0.093 & 0.086 & 0.087 & & \end{array}$

Shell thickness

$\begin{array}{llllllll}0.45 & 0.25 & 355 & 367 & 368 & 356 & 362 & 3.16 \\ 0.52 & 0.30 & 364 & 372 & 355 & 363 & 364 & 3.35 \\ 0.58 & 0.35 & 371 & 377 & 356 & 366 & 368 & 3.34 \\ \text { Mean } & & 364^{\mathrm{ab}} & 372^{\mathrm{a}} & 360^{\mathrm{b}} & 362^{\mathrm{ab}} & 365 & \\ \text { SEM } & & 4.06 & 4.00 & 3.69 & 3.33 & 3.86 & \end{array}$

Shell index

$\begin{array}{lrrrrrrrr}0.45 & 0.25 & 78.82 & 81.09 & 81.70 & 78.50 & 80.03 & 0.72 & \\ 0.52 & 0.30 & 81.03 & 82.75 & 78.89 & 81.45 & 81.07 & 0.77 & \text { NS } \\ 0.58 & 0.35 & 83.09 & 83.36 & 79.40 & 81.32 & 81.83 & 0.71 & \\ \text { Mean } & & 81.06 & 82.45 & 80.04 & 80.40 & 80.99 & & \\ \text { SEM } & & 0.90 & \mathbf{0 . 9 1} & \mathbf{0 . 8 1} & \mathbf{0 . 7 6} & \mathbf{0 . 8 6} & & \end{array}$

Shell percent

\begin{tabular}{lllllllll}
0.45 & 0.25 & 9.12 & 9.46 & 9.50 & 9.07 & $9.29^{\mathrm{b}}$ & 0.087 & \\
0.52 & 0.30 & 9.37 & 9.64 & 9.24 & 9.49 & $9.44^{\mathrm{ab}}$ & 0.089 & NS \\
0.58 & $\mathbf{0 . 3 5}$ & 9.64 & 9.80 & 9.34 & 9.52 & $9.58^{\mathrm{a}}$ & 0.087 & \\
Mean & & $\mathbf{9 . 3 9}$ & $\mathbf{9 . 6 4}$ & 9.36 & 9.35 & 9.43 & & \\
SEM & & 0.106 & 0.113 & 0.097 & 0.088 & 0.103 & & \\
\hline
\end{tabular}

* each value is a mean of 36 measurements ( 3 periods $x 12$ eggs)

means in a column or row different significant at $P \leqslant 0.05$

\section{Other egg-shell quality parameters}

Shell thickness, shell density (shell index) and dry shell content in the egg were highest in the hens receiving $150 \mathrm{FTU} / \mathrm{kg}$ of dict. The shell percentage rose from 9.29 to $9.58 \%$ (Table 2) as the phosphorous content in the feed increased. 
Amount of cracked, broken and shell-less egg , \% of total amount

\begin{tabular}{|c|c|c|c|c|c|c|}
\hline \multirow{2}{*}{$\begin{array}{l}\text { Dietary P, \% } \\
\text { total P }\end{array}$} & \multirow[b]{2}{*}{$P$ available } & \multicolumn{4}{|c|}{ Phytase supplement, FTU/kg diet } & \multirow{2}{*}{ Mean } \\
\hline & & 0 & 150 & 300 & 450 & \\
\hline \multicolumn{7}{|l|}{ Cracked eggs } \\
\hline 0.45 & 0.25 & 6.78 & 8.55 & 1.82 & 6.09 & 5.81 \\
\hline 0.52 & 0.30 & 7.75 & 2.97 & 5.85 & 2.62 & 4.80 \\
\hline 0.58 & 0.35 & 8.65 & 2.97 & 4.46 & 3.30 & 4.84 \\
\hline Mcan & & 7.73 & 4.83 & 4.04 & 4.00 & 5.15 \\
\hline \multicolumn{7}{|c|}{ Broken and without shell } \\
\hline 0.45 & 0.25 & 2.38 & 4.33 & 0.84 & 1.38 & 2.23 \\
\hline 0.52 & 0.30 & 1.96 & 1.06 & 1.74 & 0.82 & 1.39 \\
\hline 0.58 & 0.35 & 1.83 & 1.40 & 2.18 & 0.70 & 1.53 \\
\hline Mean & & 2.06 & 2.26 & 1.59 & 0.97 & 1.72 \\
\hline \multicolumn{7}{|c|}{ Cracked, broken and shell-less together } \\
\hline 0.45 & 0.25 & 9.16 & 12.88 & 2.66 & 7.47 & 8.04 \\
\hline 0.52 & 0.30 & 9.71 & 4.03 & 7.59 & 3.44 & 6.19 \\
\hline 0.58 & 0.35 & 10.48 & 4.37 & 6.64 & 4.01 & 6.37 \\
\hline Mean & & 9.78 & 7.09 & 5.63 & 4.97 & 6.87 \\
\hline
\end{tabular}

The hens laid eggs with good quality shells. However, in the groups that did not receive phytase almost $10 \%$ of the eggs had cracked shells (Table 3 ). The lowest number of damaged or broken eggs was found in hens receiving $0.30 \% \mathrm{AP}$ in their diets $(0.52 \% \mathrm{TP})$ and phytase, and in the groups receiving $450 \mathrm{FTU} / \mathrm{kg}$ of diet.

\section{Health of hens}

The health of the laying hens was very good. Only 3 hens died during the experiment.

\section{DISCUSSION}

Most of the studies on the effect of microbial phytase supplement in poultry nutrition have been carried out on chicks, because older birds are more capable of utilizing phytate phosphorous than young birds. Among the relatively small number of experiments on laying hens, most did not focus on the practical use of phytase in diets, but only on its effectiveness. Simons and Versteegh (1992) fed hens diets containing $0.30 \%$ total $P$, of which only $0.05 \%$ was non-phytate. Daily total phosphorous intake was slightly over $300 \mathrm{mg}$ per chicken, of which the layers utilized only $15 \%$, i.e. $46 \mathrm{mg}$, while after the inclusion of phytase into the 
diet, $33 \%$ i.e. $107 \mathrm{mg}$. The amount of phytate $P$ in excreta decreased from 6.6 to $3.2 \mathrm{~g}$ per $\mathrm{kg}$ DM. On the basis of these results it was concluded that the addition of $500 \mathrm{FTU}$ per $\mathrm{kg}$ of diet increases phosphorous utilization by $100 \%$ and decreased by $50 \%$ the amount of phytate phosphorous in excreta. Schöner et al. (1993) found that the utilization of phosphorous from a diet containing $0.12 \%$ AP ranged from $9-15 \%$, and after the addition of phytase, $30-38 \%$; excretion of $\mathbf{P}$ decreased therefore by $45-50 \%$, thus confirming the results of Simon and Vesteegh (1992). Feeding layers on diets made up of vegetable feeds and containing $0.12 \%$ non-phytate phosphorus, Peter (1992) found that the laying rate declined to $83 \%$ in the 31 st week of the hens life. In hens receiving phytase as an additive (the amount was not given) the laying rate was about $90 \%$ for ten more weeks. In the above studies, a maize-soyabean diet was used most frequently.

Usayran and Balnave (1995) evaluated the $P$ requirements of laying hens fed on the wheat-based diets with various $P$ levels, unsupplemented or supplemented with $500 \mathrm{FTU} / \mathrm{kg}$ of diet. The addition of phytase to a diets containing $0.32 \%$ TP $(0.12 \% \mathrm{AP})$ or $0.45 \% \mathrm{TP}(0.24 \% \mathrm{AP})$ significantly lowered the laying rate and egg weight, and increased the number of damaged shells from 5.4 to $12.4 \%$ at the lower P level and from 7.5 to $16.4 \%$ at the higher P level. On the opposite in our experiment the addition of the phytase decreased the number of damaged eggs, even in the groups of hens receiving phosphorus in amounts according to the Nutrient Requirements of Poultry (1996). Our results are, however, similar to those of Jeroch and Peter (1994) who showed that even when the addition of phytase did not increase the laying rate of hens fed wheat-based diets, it did improve egg shell quality.

Interestingly both, increasing the dietary inorganic $P$ lcvel and the addition of phylase caused a significant decrease in egg weight (Table 1). This supports the results of Budor et al. (1995), although the difference found by them was smaller $(62.4 \mathrm{vs} .61 .6 \mathrm{~g})$ than in our experiment.

The positive effect of the addition of a small amount of phytase $(150 \mathrm{FTU} / \mathrm{kg})$ on egg shell quality parameters can not be explained by the decline in egg size in these groups, since when 300 and $450 \mathrm{FTU} / \mathrm{kg}$ were added, the weight of the eggs was similar, but the shell quality worse - shell thickness, shell index, shell percentage and breaking strength deteriorated (Table 2).

The results of the present study, and our earlier papers (Kamińska et al., 1994, 1996), indicate that there is a certain optimum level of phytase supplementation, which depend on the requirements of the birds, diet composition, and that exceeding this amount can have negative consequences on the laying performance and shcll quality.

Phytic acid (myo-inositol hexaphosphatc), which forms about two thirds of the phosphorus present in seeds, creates indigestible chelates with some cations 
like $\mathrm{Ca}, \mathrm{Mg}, \mathrm{Zn}$, and with proteins, what reduces their availability (Kamińska, 1993). Enzymatic hydrolysis by phytase liberates phosphoric acid and cations from these chelates. Thiel and Weigand (1992) found that the addition of 800 FTU to maize-soyabean diets increased the level of $\mathrm{Zn}$ in the serum of broiler chickens, in carcass and their femur, as well as significantly reduced the activity of serum alkaline phosphatase. The considerable differences in the action of phytase observed by some authors may result from differences in the assumed requirements of the birds and the $P$ content of the feed and its availability, which depends on the diet composition and on the amount of microbial and plant phytase. An excess of microbial phytasc, which has an activity $74 \%$ higher than that of plant phytase (Eeckhout and De Paepe, 1991), is undesirable not only because it increase the cost of the feed, but also because it may unfavourable affects the performance. Moreover, increasing the amount of microbial phytase limits the amount of excreted $P$ only to a certain extent (Kamińska et al., 1996). At a $0.30 \%$ dietary AP content $(0.55 \% \mathrm{TP})$, the addition of phytase in amounts higher than $150 \mathrm{FTU} / \mathrm{kg}$ no longer increased the amount of $\mathbf{P}$ retained in the body but decreased $\mathrm{P}$ in excreta.

Difficulties in determining the appropriate amount of microbial phytase to be added stem, among others, from the fact that, as shown by Eeckhout and De Paepe (1994), the phytase content and activity in wheat grain may differ considerably, e.g. in from 915 to 1580 units $/ \mathrm{kg}$. This is not, however, a problem when feeding maize, because of its negligible phytase content (15 FTU/kg on average).

\section{CONCLUSIONS}

A $0.45 \%$ dietary TP $(0.25 \%$ AP) content was sufficient for hens with an $80 \%$ laying rate. A small supplement of microbial phytase $(150 \mathrm{FTU} / \mathrm{kg}) \mathrm{did}$, however, favourably affect on egg shell quality, even when the amount of available phosphorus in the diet was in agreement with recommendations $(0.35 \%)$. This improvement was manifested, among others, in a lower percentage of damaged eggs.

The addition of inorganic phosphorous and phylase in excess of this amount may have adverse effect on egg mass and shell quality parameters. 


\section{REFERENCES}

Budor J., Protais J., L'Hospitalier R., Launay M., Bougon M., Bennjean G., 1995. Effet de l'ajout de phytase dans l'alimentation de poules pondeuses sur l'excrétion et l'assimilation du phosphore, les performances et la qualité des ocufs. Arch Geflügclk. 59, 168.174

Daghir N.J., Farran M.T., Kaysi S.A., 1985. Phosphorus requirement of laying hens in a semiarid continental climate. Poultry Sci. 64, 1382-1384

Eeckhout W., De Paepe M., 1994. Total phosphorus, phytate phosphorus and phytase activity in plant feedstuffs. Anim. Feed Sci. Technol, 47, 19-29

Jeroch H., Peter W., 1994. Zur Wirksamkeit mikrobicler Phytase zu Legenhennenrationen auf Maisbzw. Weizenhasis. Bodenkultur 45, 361-368

Kamińska B.Z., 1993. The effects of dietary calcium and phosphorus levels on the egg-shell quality (in Polish). Biul. inf. Inst. Zoot. 31 (3-4), 47-56

Kamińska B.Z., Skraba B., Korcleski J,, 1994. Effect of dictary phosphorus levels and phytase supplement on performance of laying hens and egg-shell quality. Proceedings of 9th European Poultry Conference, Glasgow (Scotland), vol. 1, pp. 383-384

Kaminiska B.Z., Skraba B., Koreleski J., 1996. Effect of dietary phosphorus levels and supplemental phytase on performance of Hisex Brown laying hens and egg-shell quality. J. Anim. Feed Sci. 5, 249-259

Nutrient Requirements of Poultry. Nutritive Value of Feedstuffs (in Polish), 1996. Editor: The Kielanowski Institute of Animal Physiology and Nutrition, Jabłonna

Peter W., 1992. Investigation on the use of phytase in feeding of laying hens. Proceedings of 19th World's Poultry Congress, Amsterdam (Netherlands), Vol. 3, p. 672

Rodriguez M., Owings W.J., Sell J.L., 1984. Influence of phase feeding available phosphorus on egg production characteristics, carcass phosphorus content, and serum inorganic phosphorus levels of three commercial layer strains. Poultry Sci. 63. 1553-1562

SAS Institute, 1985. SAS Users Guide. Version 6th, Cary, NC

Schöner F.J., Hoppe P.P., Schwarz G., Wiesche H., 1993. Untersuchungen zur Phosphor-Bilanz von Legehennen bei Einsatz von Aspergillus niger Phytase. In: G. Flachovsky, R. Schubert (Editors). Vitamine und weitere Zusatzstoffe bei Mensch und Tier. Procecdings of 4th Symposium, Jena (Thüringen), Friedrich-Schiller-Universität, pp. 371-376

Simons P.C.M., Versteegh H.A.J., 1992. Het effekt van toevoeging van microbiell fytase clan leghennenvoer op de technishe resultaten en de skelet-en eischaalkwaliteit. Spelderholt Uitgave No. 568 (acc. Schöner F.J., Review of the biological effects and the ecological importance of phytase in broilers and layers. In: From Research and Practical Experience Fdition 30, Use of Natuphos in pigs and poultry. Presentation at the 4th BASF Animal Nutrition Forum, 1992)

Thicl U., Weigand E., 1992. Influence of dictary zinc and microbial phytase supplementation on Zn retention and $7 \mathrm{n}$ excretion in broiler chicks. Proceedings of the 19 World's Poultry Congress, Amsterdam (Netherland), Vol. 3, p. 460

Usayran N., Balnave D., 1995. Phosphorus requirements of laying hens fed on wheat-based diets. Brit. Poultry Sci. 36, 285-301 


\section{STRESZCZENIE}

Efektywność mikrobiologicznej fitazy w mieszankach o różnej zawartości fosforu dla kur nieśnych

Doświadczenie przeprowadzono na 216 kurach Hisex Brązowy w wieku 48-70 tygodni, przydzielonych do 12 grup po 18 ptaków trzymanych w pojedynczych klatkach. Nioski żywiono mieszankami zawierającymi $0,450,52$ i $0,58 \%$ fosforu calkowitego $(0,25,0,30, \mathrm{i} 0,35 \%$ P przyswajal-

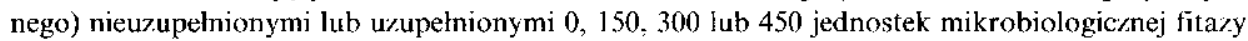
(FTU)/kg. W 54,62 i 70 tygodniu życia kur oceniono jakość jaj i skorup. Ani poziom fosforu w paszy ani dodatek fitazy nic wpłynęly na wiclkość spożycia paszy, nicśność, procentowy udzial masy żóltka w masie calego jaja i stosunek wagowy białka do źółl ka. Jaja o największej masie $(65,1 \mathrm{~g})$ uzyskano od kur żywionych paszą bez dodatku fitazy, niezależnie od poziomu P, lub miešanką o najnizszym poziomie fosforu $(P \leqslant 0,01)$. Ciężar właściwy jaj oraz ich wytrzymałość na zgniatanie, grubość skorupy, procent skorupy $\mathrm{i}$ indeks skorupy (gęstość) były największe, gdy dietę uzupełniono 150 $\mathrm{FlU} / \mathrm{kg}$, bez względu na ilość $\mathrm{P} w$ paszy, przy czym statystycznic istotne różnice $(\mathrm{P} \leqslant 0,05)$ stwicrdzono tylko dla wytrzymalości na zgniatanie i grubości skorup. Przy skarmianiu diet uzupelnionych $450 \mathrm{FTU} / \mathrm{kg}$ niek tóre parametry jakości skorup byly nawet gorsze niz be dodatku mikrobiologicznej fitazy, jednak uzupełnienie diet dodatkiem fitazy spowodowało obniżenie liczby jaj stluczonych. 